\title{
Bioethics Inserted in Oncologic Palliative Care: a Systematic Review \\ [RBVEN
}

Francisco de Castro Júnior ${ }^{1}$, Emidio Macedo Lemos Filho ${ }^{1}$, Jucier Gonçalves Júnior ${ }^{2}$, Paula Pessoa Pinheiro², Ana Lyres Grangeiro Moreira1, Cícero Cruz Macedo2,3, Maria do Socorro Martins Cardoso Novais ${ }^{3}$, Jorgyana Coimbra Macedo Cruz ${ }^{1}$, Laís Leite Fernandes ${ }^{3}$, Regiane Teixeira Silveira ${ }^{3}$, Modesto Leite Rolim Neto ${ }^{1,2,3}$, Hellen Lúcia Cruz Caldas Lins ${ }^{1,3}$, Cícera Janielly de Matos Cassiano ${ }^{1}$

\section{Abstract}

Introduction: Bioethics emerges in oncologic palliative care from the reflections of that care at the end of life for cancer patients are usually inadequate because the individuals has little relief of symptoms, adverse reactions to treatment, threats of physical, social and psychological destruction and loss of functions.

Material and Findings: Systematic review in MEDLINE, IBECS, LILACS and SCiELO from $1^{\text {st }}$ January, 2006 to $10^{\text {th }}$ January. The search was conducted with the descriptors: "Cuidados Paliativos" (DeCS); "Oncologia" (DeCS); "Morte e Morrer" (Keyword); and "Bioética" (DeCS) during the month of December 2013. The literature points out that physicians should not accept something as absolute truth; and to help them in their choices at the moment comes to bioethics, which does not provide ready answers, but, with its pluralistic view, makes us exercise the capacity for reflection in choosing the best conduits for the patient. It is necessary to rescue more widely the value of the care that was in the background before the search for the cure of diseases, which in a broader sense, encompasses human, spiritual and social aspects. In Brazil, the practice of euthanasia or assisted suicide are illegal conduct that typify the crime of murder, however, the suspension of therapeutic effort is not prohibited (SET), extensively comment, orthothanasia.

Conclusion: Despite the possible philosophical and ideological differences, it is necessary that health professionals to really take care
1 Faculty of Medicine, Estácio -FMJ, Juazeiro do Norte, Ceará, Brazil.

2 Faculty of Medicine, Federal University of Cariri, UFCA, Barbalha, Ceará, Brazil.

3 Postgraduate Program in Health Sciences, FMABC, Santo André, São Paulo, Brazil.

Contact information:

Jucier Gonçalves Júnior.

Tel: (055) (88)99176746

Address: 284, Divine Savior Street, Downtown, Barbalha, Ceará, Brazil, 63180000 .

巨" juciergjunior@hotmail.com 
of severe patients, prove conscious and attentive to the rights of the individual, the real meaning of the concepts of health and disease, issues the lack of therapeutic possibilities, extreme old age and death.

\section{Keywords}

Bioethics; Palliative Care;

Oncology.

\section{Introducion}

Cancers figure among the leading causes of morbidity and mortality worldwide, with approximately 14 million new cases and 8.2 million cancer related deaths in 2012 [1]. The National Cancer Institute (INCA) estimates that for the year 2014, there will be 576,000 new cases in Brazil [2]. With this reality in mind, the preparation and investment worldwide is need to educate health professionals that patients suffering from ills that have no cure need a own careful and focused to provide them with dignity and relief to the suffering that stage of life [3], palliative care. In this context, medical ethics today has acquired a much larger than any other historical period. Being necessary to create a new discipline, which is now known as medical bioethics [4].

Bioethics emerges in oncologic palliative care from the reflections of that care at the end of life for cancer patients are usually inadequate [5]. For the ill individual has repetitive losses that are being landmarks on the way to its end. Comes to the perceived lack of future, threats of physical, social and psychological destruction, loss of functions that had hitherto played, decreased self-esteem, feeling of being burden to others, existential concerns about life and death, harmful thoughts and negative emotions, little relief of symptoms, adverse reactions to treatment, lack of intimacy, companionship or unwanted loneliness, isolation from family and friends, concern about pending or unfinished subjects [6].

The study was based on the following guiding question: What are the updates that have taken place in the world for the period 2006-2014 in oncologic palliative care with a view bioethics? Considering the epidemiological transition in the world and the emergence of chronic degenerative diseases such as cancer, debates in the palliative management of patients should be seen as public health problems. However, during the provision of palliative care arise various problems/questions about "caring for a cancer patient," these impasses must be supported in the light of bioethics. In order to obtain an overview of bioethics inserted in oncologic palliative care, this study aimed at a systematic review of studies published in this area. The hypothesis is that the current biomedical training does not include the demands of healthcare today, especially in guiding questions to the treatment of terminal patients, requiring, therefore, a broad overhaul and insert still in Academy consistently of topics such as Palliative Care and Thanatology.

\section{Methodology}

Systematic review qualitative whose selection of studies was performed broadly through the Biblioteca Virtual em Saúde (BVS), which hosts recognized databases. The search was conducted with the descriptors: "Cuidados Paliativos" (DeCS); "Oncologia" (DeCS); "Morte e Morrer" (Keyword); and "Bioética" (DeCS) during the month of December 2013.

The complementation of the search for descriptors using the keyword "Morte e Morrer" is justified because this term, though not cataloged in DeCS, is often used to characterize studies dea- 
ling with the subject of this review. The result led the search to online databases: Medical Literature Analysis and Retrieval System Online (MEDLINE), Latin American and Caribbean Health Sciences (LILACS), Bibliographic Index Spanish in Health Sciences (IBECS) and Scientific Electronic Library Online (SciELO). The period raised in the literature was $1^{\text {st }}$ January, 2006 to $10^{\text {th }}$ January, 2014. The reason for defining the search for the period 2006-2014 emerged the need to map the main reflections that guide the bioethical issues with interface in oncologic palliative care.

The compilation of data was during the month of April 2014. The selection of manuscripts occurred primarily by analyzing the titles and abstracts. After the articles identified by the search strategy were evaluated independently by the authors, consonant with the following inclusion criteria: (1) articles that had on the title is at least one of the terms described in the search strategy; (2) articles written in English, Portuguese or Spanish; (3) papers discussing bioethical interfaces of palliative care in oncology overlooking the main and most current evidence; (4) original studies with full text available through the CAPES Journal Portal (Coordenação de Aperfeiçoamento Pessoal de Nível Superior), a virtual library created by the Brazilian Ministry of Health and restricted content to authorized users. Exclusion criteria were: (1) no original studies such as Letters to the Editor, prefaces, short communications, reviews and editorials; (2) studies with samples animals; (3) items the methodological design is not well defined. Manuscripts were repeated on more than one databases were counted only once.

Subsequently, each selected article was read in full and important data for this review were collected and organized in a spreadsheet containing: Authors, Year, Journal, Characterization of Sample and Main findings (Table 1). Some of the items found contemplate the theme of bioethics inserted in palliative care in oncologic patients and other pa- tients outside the therapeutic possibility with recent HIV infection, COPD and heart failure grade IV. Considering that this study focuses on bioethical issues in palliative care faces the oncology, data correlated to other patients outside the therapeutic possibility, which did not have cancer, were not analyzed in the study.

The research strategy in the BVS, this took place in four phases: a) the descriptors crossed \# 1 AND \# 2 , resulting in nineteen articles; b) crossed \# 2 AND \# 3, resulting in nineteen articles; c) used is the descriptor \# 2 affording a total of 12,175 manuscripts; d) crossed the descriptors \# 4 AND \# 1, yielding 58 articles. In order to increase the data analysis, the next step involved the grouping, for heuristic reasons, the results on two themes: "Bioethics in Palliative Care"; and "Bioethics in Palliative Care: those covered issues on Euthanasia, Dysthanasia and Orthothanasia".

This was a literature review therefore no involving recruitment of patients. In this sense, ethical approval was not necessary. This revision is using the PRISMA protocol (http://www.prisma-statement.org/).

\section{Results}

According to the strategy adopted were initially found 12,271 manuscripts. Articles repeated in the course of the search strategy were computed in the count only once. After analyzing the titles and abstracts, we obtained a total of 28 articles selected according to the eligibility criteria and are therefore excluded 12,243 . The selection was rigorous due to the large number of studies on the theme. The 28 studies were divided into two predetermined categories, namely: "Bioethics in Palliative Care" and "Bioethics in Palliative Care: those covered issues on Euthanasia, Dysthanasia and Orthothanasia" (Figure 1). 
Table 1. Bioethics inserted in Oncology Palliative Care: Key Findings.

\begin{tabular}{|c|c|c|c|c|}
\hline Author (Year) & Periodic & $\begin{array}{l}\text { Type os } \\
\text { Study }\end{array}$ & Sample Characterization & Main Findings \\
\hline \multicolumn{5}{|c|}{ Bioethics in Palliative Care } \\
\hline $\begin{array}{l}\text { Garcia-Schinzari } \\
\text { e Santos (2014) } \\
\text { [8] }\end{array}$ & $\begin{array}{l}\text { Rev Paul } \\
\text { Ped }\end{array}$ & $\begin{array}{l}\text { Literature } \\
\text { Review, } \\
\text { Descriptive }\end{array}$ & $\begin{array}{l}\text { Articles from January } 2002 \text { to } \\
\text { December } 2011\end{array}$ & $\begin{array}{l}\text { Participants most research were the children's parents and health professionals. The main } \\
\text { pathology was addressed cancer and nurses were the most mentioned professionals. } \\
\text { The types of care provided were related to the physical aspects, the general care and } \\
\text { psychological, social and spiritual (less emphasis). The main findings were: little emphasis } \\
\text { on the needs of children, importance of including the family in care delivered and lack of } \\
\text { preparedness of the health team. }\end{array}$ \\
\hline $\begin{array}{l}\text { Wittmann-Vieira } \\
\text { e Goldim (2012) } \\
\text { [9] }\end{array}$ & $\begin{array}{l}\text { Acta Paul } \\
\text { Enferm }\end{array}$ & $\begin{array}{l}\text { Cross- } \\
\text { sectional } \\
\text { study and } \\
\text { Quantitative }\end{array}$ & $\begin{array}{l}89 \text { patients out of therapeutic } \\
\text { possibilities of cure, admitted to the } \\
\text { Palliative Care Unit (PCU) of Porto } \\
\text { Alegre Clinical Hospital (PACH). }\end{array}$ & $\begin{array}{l}\text { Patients demonstrated satisfaction with the ability to establish social, personal and intimate } \\
\text { relationships, even when hospitalized. }\end{array}$ \\
\hline $\begin{array}{l}\text { Chaves et. al. } \\
\text { (2011)[10] }\end{array}$ & Rev Dor & $\begin{array}{l}\text { Documen- } \\
\text { tary } \\
\text { research }\end{array}$ & $\begin{array}{l}23 \text { studies on bioethics and palliative } \\
\text { care. }\end{array}$ & $\begin{array}{l}\text { The issue of education is imperative in community awareness and reformulation of public } \\
\text { policies and curricula of courses aimed at training health professionals who can provide } \\
\text { dignified care in addition to professional technical competence, nothing and no one } \\
\text { replaces the human person as the source and healing factor for the patient. }\end{array}$ \\
\hline $\begin{array}{l}\text { Pinto et. al. } \\
\text { (2011)[11] }\end{array}$ & $\begin{array}{l}\text { Cogitare } \\
\text { Enferm }\end{array}$ & Qualitative & $\begin{array}{l}13 \text { professionals from the nursing staff } \\
\text { of a teaching hospital in the interior of } \\
\text { São Paulo. }\end{array}$ & $\begin{array}{l}\text { Assistance to patients was limited to the physical care and the confrontation occurred } \\
\text { with individual strategies, may jeopardize patient safety. The unprepared professional } \\
\text { to emotional care was the main difficulty reported, with evidence of their need for } \\
\text { training. }\end{array}$ \\
\hline $\begin{array}{l}\text { Calderón, } \\
\text { Pazitková, } \\
\text { Naranjo (2010) } \\
\text { [4] }\end{array}$ & $\begin{array}{l}\text { Rev Cubana } \\
\text { Med Gen } \\
\text { Integr }\end{array}$ & $\begin{array}{l}\text { Review } \\
\text { Article }\end{array}$ & $\begin{array}{l}25 \text { studies on bioethics in palliative } \\
\text { care. }\end{array}$ & $\begin{array}{l}\text { The survey of ethical dilemmas at the end of life is not intended to resolve them once } \\
\text { and for all, but, first of all, understand them properly, understand the arguments of the } \\
\text { different positions, their weights and limitations, so that it may have enough information } \\
\text { to realization of a personal judgment on the issue. }\end{array}$ \\
\hline
\end{tabular}




\begin{tabular}{|c|c|c|c|c|}
\hline Author (Year) & Periodic & $\begin{array}{l}\text { Type os } \\
\text { Study }\end{array}$ & Sample Characterization & Main Findings \\
\hline $\begin{array}{l}\text { Sousa et.al. } \\
\text { (2010)[3] }\end{array}$ & $\begin{array}{l}\text { Rev Cubana } \\
\text { Enfermer }\end{array}$ & $\begin{array}{l}\text { Review of } \\
\text { qualitative } \\
\text { literature }\end{array}$ & 08 articles dealing about bioethics. & $\begin{array}{l}\text { In some studies, the principles of bioethics application, which already allows envision a } \\
\text { better outlook for the near future. However other realities present, even if subtly, the } \\
\text { noncompliance of these principles, which also reflects the need for change. }\end{array}$ \\
\hline $\begin{array}{l}\text { Chaves e } \\
\text { Massarollo } \\
(2009)[11]\end{array}$ & $\begin{array}{l}\text { Rev EsC } \\
\text { Enferm USP }\end{array}$ & $\begin{array}{l}\text { Cross- } \\
\text { sectional } \\
\text { study and } \\
\text { Qualitative }\end{array}$ & $\begin{array}{l}10 \text { nurses working in the ICU of a } \\
\text { general hospital in the city of São } \\
\text { Paulo. }\end{array}$ & $\begin{array}{l}\text { Ethical dilemmas linked were found to: diversity of values; presence of terminal patients } \\
\text { in the ICU; uncertainties about terminal illness and limits of intervention to prolong the } \\
\text { lives of patients; decision making of disagreement; rejection of the process of dying by the } \\
\text { patient's family and the lack of clarification of the family and the patient. }\end{array}$ \\
\hline $\begin{array}{l}\text { Kuschner et. al. } \\
\text { (2009)[12] }\end{array}$ & Chest & $\begin{array}{l}\text { Retros- } \\
\text { pective } \\
\text { description }\end{array}$ & 04 patients with lung cancer & $\begin{array}{l}\text { We have developed an initiative to improve the quality of the approach end of life } \\
\text { care in our ICU, by improving communication and understanding of palliative care } \\
\text { practices, and to avoid ethical conflicts surrounding the end of life care as well how to } \\
\text { improve patient care. }\end{array}$ \\
\hline $\begin{array}{l}\text { Floriani e } \\
\text { Schramm }(2008) \\
{[14]}\end{array}$ & $\begin{array}{l}\text { Ciênc. saúde } \\
\text { coletiva }\end{array}$ & $\begin{array}{l}\text { Literature } \\
\text { review }\end{array}$ & $\begin{array}{l}59 \text { articles on practices at the end } \\
\text { of life, with particular emphasis on } \\
\text { palliative care, a model expanding } \\
\text { worldwide, and the perspective of } \\
\text { bioethics. }\end{array}$ & $\begin{array}{l}\text { Stand out certain difficulties and challenges around the centrality of autonomy, considered } \\
\text { one of the cornerstones of good practices of care at end of life. }\end{array}$ \\
\hline $\begin{array}{l}\text { Freitas Lopes. } \\
\text { Chagas e Jorge } \\
\quad(2007)[15]\end{array}$ & $\begin{array}{l}\text { Rev gaúcha } \\
\text { enferm }\end{array}$ & $\begin{array}{l}\text { Literature } \\
\text { review }\end{array}$ & $\begin{array}{l}28 \text { studies on the understanding of } \\
\text { health professionals on the bioethical } \\
\text { principle of autonomy. }\end{array}$ & $\begin{array}{l}\text { Bioethics helps to reflect on professional practice overcoming individualism brought by } \\
\text { progress, stimulating interpersonal relationships, defending rights that actualize human } \\
\text { dignity. }\end{array}$ \\
\hline
\end{tabular}




\begin{tabular}{|c|c|c|c|c|}
\hline Author (Year) & Periodic & $\begin{array}{l}\text { Type os } \\
\text { Study }\end{array}$ & Sample Characterization & Main Findings \\
\hline $\begin{array}{l}\text { Machado, } \\
\text { Pessini e Hossne } \\
\text { (2007)[16] }\end{array}$ & $\begin{array}{l}\text { Rev } \\
\text { Bioethikos }\end{array}$ & $\begin{array}{l}\text { Cross- } \\
\text { sectional } \\
\text { study and } \\
\text { Quantitative }\end{array}$ & $\begin{array}{l}21 \text { physiotherapists, } 12 \text { doctors and } 25 \\
\text { nurses who work in multidisciplinary } \\
\text { teams in the ICU. }\end{array}$ & $\begin{array}{l}\text { They make urgently needed changes in the curriculum of health professionals, } \\
\text { contemplating the teaching of palliative care and assisting professionals in bioethics } \\
\text { reflections for better decision ahead for the patient out of therapeutic possibilities. }\end{array}$ \\
\hline $\begin{array}{l}\text { Pontes et.al. } \\
\text { (2007)[17] }\end{array}$ & $\begin{array}{l}\text { Rev } \\
\text { Bioethikos }\end{array}$ & $\begin{array}{l}\text { Qualitative } \\
\text { descriptive } \\
\text { study of } \\
\text { literature }\end{array}$ & $\begin{array}{l}26 \text { articles about death and dying in } \\
\text { their bioethical nuances. }\end{array}$ & $\begin{array}{l}\text { The difficulty in doctor-patient communication, fear of feelings, isolation of emotions } \\
\text { (neutrality) and the dynamics of omnipotence and idealization (medical identification with } \\
\text { the image of fullness), are some of the factors that haunt the health care. }\end{array}$ \\
\hline $\begin{array}{l}\text { Rodriguez } \\
(2006)[18]\end{array}$ & ARS Médica & $\begin{array}{l}\text { Literature } \\
\text { review }\end{array}$ & $\begin{array}{l}\text { Papers discussing the relevant ethical } \\
\text { principles in palliative medicine. }\end{array}$ & $\begin{array}{l}\text { It is necessary to keep in mind the ethical principles that protect the dignity of the person, } \\
\text { even in conditions of extreme weakness, as is usually the final stage of life. Respect } \\
\text { for human dignity and acceptance of finitude of the human condition are the two } \\
\text { fundamental attitudes that guide the practice of palliative medicine. }\end{array}$ \\
\hline \multicolumn{5}{|c|}{ Bioethics in Palliative Care: those covered issues on Euthanasia, Dysthanasia and Orthothanasia } \\
\hline Author (Year) & Periodic & $\begin{array}{l}\text { Type os } \\
\text { Study }\end{array}$ & Sample Characterization & Main Findings \\
\hline $\begin{array}{l}\text { França (2013) } \\
\qquad[20]\end{array}$ & Rev bioét & $\begin{array}{l}\text { Literature } \\
\text { review }\end{array}$ & $\begin{array}{l}\text { Studies about the bioethical } \\
\text { implications in euthanasia process. }\end{array}$ & $\begin{array}{l}\text { It is not about being for or against this or that form of euthanasia because we advocate } \\
\text { as only care to carefully follow the new concept of death, knowing if the patient is } \\
\text { alive or not. Thus, many of the "future directives" (advance directives - AD) such as the } \\
\text { "living wills" (living wills), or "legal powers" (durable powers of attorney), both legal } \\
\text { instruments for subrogated decisions created based on the "law of self-determination } \\
\text { of the patient (patient self-determination act - PSDA) to compulsorily in some more } \\
\text { consumerist climates, especially when internment of poor people, no longer will have } \\
\text { greater meaning. }\end{array}$ \\
\hline
\end{tabular}




\begin{tabular}{|c|c|c|c|c|}
\hline Author (Year) & Periodic & $\begin{array}{l}\text { Type os } \\
\text { Study }\end{array}$ & Sample Characterization & Main Findings \\
\hline $\begin{array}{l}\text { Menezes e } \\
\text { Ventura (2013) } \\
{[21]}\end{array}$ & RBCS & $\begin{array}{l}\text { Literature } \\
\text { review }\end{array}$ & $\begin{array}{l}29 \text { studies on euthanasia, dysthanasia } \\
\text { and orthothanasia in the legal } \\
\text { framework. }\end{array}$ & $\begin{array}{l}\text { The question raised by euthanasia is not restricted to the substitution value of holiness/ } \\
\text { sacredness of life for any other value. We must think about the possible ways of } \\
\text { understanding and respect for the value of life, given the emergence of individual or } \\
\text { collective demand. }\end{array}$ \\
\hline $\begin{array}{l}\text { Barroso- } \\
\text { Fernandez e } \\
\text { Abalo }(2012)[22]\end{array}$ & Psicol salud & $\begin{array}{l}\text { Literature } \\
\text { review }\end{array}$ & $\begin{array}{l}47 \text { manuscripts from } 1974 \text { to } 2011 \text { on } \\
\text { euthanasia and palliative care. }\end{array}$ & $\begin{array}{l}\text { It is suggested the recovery of the sense of the word euthanasia, such as was proposed } \\
\text { by the Greeks, strengthening the tradition of social trust in physicians as advocates of life } \\
\text { and not as death dispensers. It is recommended to increase medical training in bioethics } \\
\text { area, palliative care and construction of more precise instruments with which to explore } \\
\text { the attitudes at the end of life. }\end{array}$ \\
\hline $\begin{array}{l}\text { Oliveira Júnior e } \\
\text { Oliveira (2012) } \\
\quad[23]\end{array}$ & $\begin{array}{l}\text { Rev } \\
\text { Bioethikos }\end{array}$ & $\begin{array}{l}\text { Review } \\
\text { critical }\end{array}$ & $\begin{array}{l}15 \text { studies on the legal elements } \\
\text { contained in the discussion of } \\
\text { eutanása and orthotanasia. }\end{array}$ & $\begin{array}{l}\text { The proposal is presented in the draft is to create a penal type with specific nomem juris } \\
\text { euthanasia, away from the circle surrounding the manslaughter. Already orthothanasia the } \\
\text { legal framework is totally different. The new law comes as exclusion of illegality, which } \\
\text { provides the legal character of the practice of orthotanasia. }\end{array}$ \\
\hline $\begin{array}{l}\text { Bomtempo } \\
(2011)[24]\end{array}$ & $\begin{array}{l}\text { Rev } \\
\text { Internacional } \\
\text { do Direito e } \\
\text { da Cidadania }\end{array}$ & $\begin{array}{l}\text { Literature } \\
\text { review }\end{array}$ & $\begin{array}{l}22 \text { studies on the legality of the } \\
\text { orthothanasia inserted in the } \\
\text { perspective of the right to die } \\
\text { with dignity, placed in the context of } \\
\text { the democratic rule of law. }\end{array}$ & $\begin{array}{l}\text { Orthothanasia obey the Brazilian Constitution, as it aims to ensure a dignified death to the } \\
\text { terminal patient, permeated by the dignity of the human person, as opposed to inhuman } \\
\text { and degrading treatment prohibited by the Constitution. }\end{array}$ \\
\hline $\begin{array}{l}\text { Junges et. al. } \\
\text { (2010)[25] }\end{array}$ & Rev bioét & $\begin{array}{l}\text { Literature } \\
\text { review }\end{array}$ & $\begin{array}{l}25 \text { items printed or online that focused } \\
\text { on orthotanasia. }\end{array}$ & $\begin{array}{l}\text { The extension of the patient's life establishes very complex situations, but the limit to invest } \\
\text { should be set for the conception of dignified death, coupled with the full awareness of } \\
\text { the limitations of interventions. The most appropriate solution for each situation is directly } \\
\text { linked to the dignity of the person suffering the inevitable process of death, respecting } \\
\text { their decisions. }\end{array}$ \\
\hline $\begin{array}{l}\text { Marta, Hanna e } \\
\text { Silva (2010)[26] }\end{array}$ & $\begin{array}{l}\text { Diagn } \\
\text { Tratamento }\end{array}$ & $\begin{array}{l}\text { Critical } \\
\text { review }\end{array}$ & $\begin{array}{l}\text { Articles about palliative care and } \\
\text { orthothanasia. }\end{array}$ & $\begin{array}{l}\text { It is legitimate and ethically correct, the doctor, based on his convictions, abdicate provide } \\
\text { treatments that extend painful and precarious life. Life is a right to be asserted and not an } \\
\text { unconditional imposition to be fulfilled. }\end{array}$ \\
\hline
\end{tabular}




\begin{tabular}{|c|c|c|c|c|}
\hline Author (Year) & Periodic & $\begin{array}{l}\text { Type os } \\
\text { Study }\end{array}$ & Sample Characterization & Main Findings \\
\hline $\begin{array}{l}\text { Biondo, Silva e } \\
\text { Seco }(2009)[27]\end{array}$ & $\begin{array}{l}\text { Rev } \\
\text { Latino-am } \\
\text { Enfermagem }\end{array}$ & $\begin{array}{l}\text { Exploratory, } \\
\text { descriptive } \\
\text { and Quanti- } \\
\text { tative. }\end{array}$ & $\begin{array}{l}\text { Twenty-seven nurses working in nine } \\
\text { Intensive Care Units (ICU) existing in a } \\
\text { large teaching hospital in São Paulo. }\end{array}$ & $\begin{array}{l}\text { The foundation of professional acting of nurses was not homogeneous and knowledge } \\
\text { on the subject is still limited. The search for orthothanasia, bioethical principles and } \\
\text { humanization of care should be foundations of their assistance. }\end{array}$ \\
\hline Horta (2009)[28] & Rev bioét & $\begin{array}{l}\text { Systematic } \\
\text { Review }\end{array}$ & $\begin{array}{l}12 \text { articles about the dysthanasia, } \\
\text { orthothanasia and euthanasia. }\end{array}$ & $\begin{array}{l}\text { There is urgent need to put an end to the serious problem of dysthanasia in Brazilian } \\
\text { hospitals. Defends the right to life as the first human right and the condition for all others. }\end{array}$ \\
\hline $\begin{array}{l}\text { Menezes, Selli e } \\
\text { Alves (2009)[29] }\end{array}$ & $\begin{array}{l}\text { Rev } \\
\text { Latino-am } \\
\text { Enfermagem }\end{array}$ & $\begin{array}{l}\text { Exploration } \\
\text { and } \\
\text { qualitative } \\
\text { study }\end{array}$ & $\begin{array}{l}10 \text { nurses in the intensive care unit of } \\
\text { adult in a hospital Porto Alegre, Rio } \\
\text { Grande do Sul. }\end{array}$ & $\begin{array}{l}\text { Nurses interpret dysthanasia as extending life with pain and suffering, while terminal } \\
\text { patients are submitted to futile treatments that do not benefit. They also identify } \\
\text { dysthanasia using orthothanasia elements to explain it. }\end{array}$ \\
\hline $\begin{array}{l}\text { Nunes (2009) } \\
\quad[30]\end{array}$ & Rev bioét & $\begin{array}{l}\text { Literature } \\
\text { review }\end{array}$ & 32 articles about orthotanasia. & $\begin{array}{l}\text { The issue of orthothanasia needs, on the one hand, a broad consensus among health } \\
\text { professionals about the great ethical principles to adopt and, secondly, a broad and } \\
\text { participatory social discussion. Only the true exercise of deliberative democracy could } \\
\text { legitimize orthothanasia as proper medical practice. }\end{array}$ \\
\hline $\begin{array}{l}\text { Villas-Bôas } \\
(2008)[31]\end{array}$ & Rev bioét & $\begin{array}{l}\text { Critical } \\
\text { review }\end{array}$ & $\begin{array}{l}43 \text { studies on orthothanasia against } \\
\text { the Brazilian criminal law. }\end{array}$ & $\begin{array}{l}\text { The restriction of artificial resources is not a crime if they do not represent an effective } \\
\text { benefit to the patient and are only therapeutic obstinacy conditions. The indication or } \\
\text { contraindication of a measure is medical decision that should be discussed with the patient } \\
\text { and family order to ensure the dignity of the human person at the end of life. }\end{array}$ \\
\hline Lima (2008)[32] & Jus Societas & $\begin{array}{l}\text { Literature } \\
\text { review }\end{array}$ & $\begin{array}{l}24 \text { studies on orthothanasia from a } \\
\text { legal point of view. }\end{array}$ & $\begin{array}{l}\text { Some placements are firming and transdisciplinary discussion on the applicability of } \\
\text { orthothanasia as a way to tutelary a dignified death sedimented up with fulcrum principles in } \\
\text { (bio) - ethical, especially the principle of freedom of choice, and the constitutional primacy of } \\
\text { human dignity, culminating in guidelines that involve the most supreme good of mankind, the } \\
\text { coated life of dignity. }\end{array}$ \\
\hline
\end{tabular}


Figure 1: Flow chart summarizing the procedure for selecting studies for review.

BVS

1)Cuidados Paliativos (DeCS); 2) Oncologia (DeCS); 3) Morte e Morrer (keyword); 4) Bioética (DeCS);

$\&$

Index: Title

Period: January 01, 2006 to January 10, 2014

\section{Inclusion criteria}

1. Articles available online in its entirety;

2. Articles written in English, Portuguese and/or Spanish;

3. Articles that focused the interfaces of palliative care in oncology overlooking the main and most current evidence

\section{Reference with the} full text analyzed for eligibility $(n=28)$
12,243 items excluded after title and summary analysis:
a) Does not address the topic $(n=1,533)$;
b) They were not available online and in full $(n=5,934)$;
c) Items that were not in English/Portuguese $(n=4,660)$;
d) Repeated articles $(n=20)$;
e) Prefaces $(n=16)$;
f) Letters to the Editor $(n=15)$;
g) Comments $(n=25)$;
h) Editorial $(n=30)$;
i) Articles whose sample were animals $(n=10)$;

\section{Studies included in the review} $(n=28)$

\section{Discussion}

\section{Bioethics in Palliative Care}

In Oncology, fifty percent of patients have been diagnosed with an advanced cancer and of these, fifty percent will be out of therapeutic possibilities [19]. This reality includes the health care needs set in the $\mathrm{XXI}$ century, and shows that at no other time as the current one has raised so many and complex moral problems to doctors, and never as today if required an appropriate ethics training for professionals health [4]. In this context, the dictates of principialist current bioethics should govern any action that is related to life, that is, from birth to terminality [3].
Thus, palliative care is fully inserted within the bioethical reflection, especially as regards the decision-making process involved with terminal patients [8]. In this regard, Chaves et. al. [11] brings the five principles relevant in the care of terminally ill patients [18]:

- The proportionality principle is used to resolve the collision of legal principles, which are understood as assets, property and interests. It is proposed to elect the most reasonable solution for concrete legal problem within the social, economic, cultural and political circumstances that involve the issue, without departing from the legal parameters; 
- The Double Effect Principle is ethical rule referred will permissibility of actions which follow two effects simultaneously, one good and one bad; as soon, actions that have "double effect":

- The Prevention Principle predict the possible complications and/or symptoms that most frequently present in the evolution of certain clinical condition;

- The Principle of Non Abandonment recalls that, except in cases of serious conscientious objection, it would be unethical to abandon the patient because this refusal certain therapies, even when the doctor considers this inadequate refusal;

- The Principle of Truthfulness; which, according to Marta, Hanna and Silva [26] is the constant respect for the truth. Based on interpersonal trust relationships. It means speaking truth to patients and their families, enabling them concrete participation in decision making.

The literature points out that physicians should not accept something as absolute truth; and to help them in their choices at the moment comes to bioethics, which does not provide ready answers, but, with its pluralistic view, makes us exercise the capacity for reflection in choosing the best conduits for the patient [16]. Floriani and Schramm [14] highlight that treatments considered futile in patients with terminal illnesses are of usual occurrence in our environment often with the death of these patients in intensive care units when we have a bad prognosis for a considerable time previous. So, do not die at home, but usually alone and in hospital, in a bed Intensive Care Unit (ICU), surrounded by "tubes" and "wire" [13].

Chaves and Massarollo [11] suggest that it is necessary to rescue more widely the value of the care that was in the background before the search for the cure of diseases, which in a broader sense, encompasses human, spiritual and social aspects.
The authors [11] also believe that this care is necessary for the rehabilitation of patients so that they can live with its limitations, ie even they do not have therapeutic possibilities of clinical cure, which may have their condition of to be human and be socially active not only in the biological dimension.

In terminal situations, especially ICU, it is known that the therapeutic resources are large in order to maintain life artificially. If there is no reasoning returned to bioethical principles of beneficence, non-maleficence, justice and autonomy always taking into consideration the humanization, there are higher chances of incurring dysthanasia measures, bringing more suffering and the patient moving away from orthothanasia [27].

Kuchner et al. [12] adds that the explicit absence of the basic rules governing the withdrawal of lifesustaining treatment (WOLS) in ICU interventions with administration of large doses of sedatives and analgesics, or stopping of mechanical ventilation, can be interpreted as attempt to intentionally hasten the patient's death rather than relieve pain and suffering or allow natural death by disease.

Pontes et al. [17] goes beyond those tests, reporting that many other bioethical issues can be raised as to choose the most advantageous treatment for the patient who is front of an acute phase of their illness, the moment and the way of informing family about this fact and also the decision on the prescription sedatives or opioids for pain relief. The authors highlight that questions still remained unresolved in the context of psychology and the law does not fully clarify the issue, making it therefore necessary to walk a path beyond the existential merit, or enter into aspects of philosophy and anthropology, so to understand the complexity of this issue.

Another aspect of ethical importance is sedation. The terminal sedation is also defined with the prescription of psychotropic agents, particularly benzodiazepines and neuroleptics, in order 
to control psychological symptoms (insomnia, anxiety attacks, agitation), or render the patient unconscious for certain situations difficult to control, as in cases of hemorrhage [19]. Palliative sedation is often necessary in cancer patients in their process of death/dying. However, this can trigger emotional and ethical disorders in professionals involved in this care. To the relief of these disorders is important to encourage some attitudes, as the approach of multidisciplinary team to resolve conflicting opinions; provide scheduled meetings with patients and families, for various clarifications; promote training and discussions periodicaIly about sedation and the ethical aspects involved in this practice [19].

Machado, Pessini and Hossne [16] evaluated the ethical dilemmas about conduct for patients outside the therapeutic possibility in a multidisciplinary team working in the ICU, showed very clearly a deficit in training and health team unpreparedness in deal with the issues raised in the ambience death and dying as well as bioethics.

\section{Bioethics in Palliative Care: those covered issues on Euthanasia, Dysthanasia and Orthothanasia}

The practice of euthanasia, dysthanasia and orthothanasia are highlighted in bioethical discussions in oncologic palliative care. Although it is understood that conceptualizing an integral manner "euthanasia", "dysthanasia" and "orthothanasia" is not easy in a work environment in which, often, professionals can come across some of these situations, understand the subject is of utmost importance [27]. Thus, Junges et al [25] bring the following settings for euthanasia, dysthanasia and orthothanasia, respectively:

- Euthanasia, process death of a patient by intervention with the ultimate goal of leading to death, relieving unbearable suffering, is the most popular practice. His form of punishment depends on the country in which it occurs. In the Netherlands, it is not considered a crime. Greece, Poland, Austria and Norway have mild punishments. In Germany, Italy and Switzerland its practice is not considered murder and, by law, must be declared as a special case;

- Disthanasia is in contrast to orthothanasia therefore aims to prolong life at any cost, even with patient suffering. It is very questionable practice because delay the agony of patients without these have expectation of cure or improvement in quality of life;

- Etymologically, orthothanasia correct means death - ortho: right; Thanatos: death. Means no artificial prolongation of the dying process, beyond what would be the natural process. So, orthothanasia sets exactly opposed to the concept of Refusing Life Support, continued and persistent use of measures that sustain the lives of patients with advanced disease with prolonged maintenance of biological vital systems and consequent delay of death, configuring up a known frame as medical futility [14].

Euthanasia can be active or passive; voluntary or involuntary [22], and active involves the action of a doctor, with lethal injection administration; passive refers to the omission of features such as medications, hydration and nutrition; voluntary euthanasia respect the wish of the patient and the involuntary refers to their inability to express the consent [21].

In recent years, the term "passive euthanasia" brought formidable confusion to the debates to be extended to those situations where it is considering the suspension of certain medical therapies aimed at prolonging the life of terminal patients, however, today, the question that must be asked is: there are situations in which, even being able to extend the life, is morally justified to omit the medical action? Says Sandro Spinsanti that "the omission is legitimate when it lets the patient goes 
naturally in the process of dying, resigning to the stiffening that qualify from therapeutic obstinacy". According to him, "the doctor, dominated by obstinacy, considers its sole duty to extend as long as possible the functioning of the patient's body, in any condition in which it occurs, ignoring every dimension of human life other than the biological and especially, neglecting the quality of life that is achieved in this way and the explicit or presumed will of the patient [28].

Marta, Hanna and Silva [26] reported that the engagement and the obligation to the promotion of quality of life in terminal patients allowed us to develop a new concept that decries all forms of mistanásias (painful and miserable death out and before its time) without however, euthanize and / or dysthanasia. This is the orthotanasia. Thus, orthothanasia does not anticipate the moment of death; the patient does not have caused his death, since this is a result of a natural process, inexorable which overcome at all human beings [26].

The issue of dysthanasia, therapeutic obstinacy, or funnel and useless treatment is controversial [11], should prevail sacredness or quality of life? The first is what human life is the dimension that requires the dignity of every man and every woman. And the quality of life is a combination of physical and psychic abilities that provide to humans live reasonably well [20]. Menezes, Selli and Alves [29] emphasize the futile treatment could be replaced by palliative care. But we see that the family does not accept the terms of their seriously ill relatives, stating that prefer to keep the treatment. Thus, the literature evidence a deficit in communication capacity among health professionals and family members/users, a position confirmed by a study in Chile, with people very close to the deceased, which showed that patient satisfaction with the care provided, communication, the frequency of attention and good professional humor are factors that affect the quality of the dying process, regardless of the die at home or in the hospital [10].

The suspension or abstention of disproportionate means of treatment - including cardiopulmonary resuscitation and non-resuscitate orders - are now common practice throughout the Western world, crystallizing the notion that human life deserves to be respected in their dignity, especially at the end of life. Although traditionally not obtaining informed consent has gradually generalized the notion that even in these cases should involve the patient in decision-making, in order to clear it up properly on the circumstances surrounding the terminally of his life [30].

From a legal point of view, Bomtempo [24] points out that the dignity, based on Article 1, section III, of the Constitution of 1988 says that Brazil is in a democratic state that has as one of its foundations to human dignity; this way, the author stresses that the right to life is provided for in the caput of Article 5 of the Constitution of 1988 which states that all are equal before the law, guaranteeing the inviolability of the right to life, with an inherent value the human person; is a fundamental guarantee.

Villas-Bôas [31] refers in Brazil, the Penal Code punishes, in Article 121, paragraph 1, albeit with lesser sentence, murder impelled by relevant moral value - identified, according to the exposure of the Code own reasons, with euthanasia, when this value is compassion for the sick suffering. It does not account, however, than is understanding the limits that kill someone, which it is for doctrine and jurisprudence specify. It is true that it may be by action or omission. In addition, other penal types can also tangent matter.

In the draft of the Penal Code, prepared by a committee of jurists in order to do a review in criminal types and adequacy of new forms of illicit, kept euthanasia in the following terms [23]: 
Art. 122. Killing, for pity or compassion, terminally ill patient, and higher imputable, at their request, to shorten her unbearable physical suffering because of serious illness:

\section{Penalty - imprisonment for two to four years.}

1 The judge will no longer apply the penalty evaluating the circumstances of the case and the family relationship or narrow agent bonds of affection with the victim (p. 57). The Draft was not accepted.

According to Lima [32] in Brazil, the practice of euthanasia or assisted suicide are illegal conduct that typify the crime of murder, however, the suspension of therapeutic effort is not prohibited (SET), extensively comment, orthothanasia. The applicability of orthothanasia is permitted in many countries, and in Brazil, is implicitly safeguarded through legal principles, consubstantiated in ethical and moral principles. Bomtempo [24] corroborates the argue that orthothanasia is claimed to the right to a dignified death, coextension of human dignity, and is permeated by the constitutional principles of life, equality, freedom, and the right to health, too, orthothanasia meets the bioethical principles. However, the legal uncertainty brought about by the absence of specific legislation, leads to the permanence of the practice of dysthanasia [32]; Menezes and Ventura [29] including, underline the concern among doctors, with the formulation of legal support to their professional practice in the case of withdrawal of technology to maintain life. In such cases the interpretation is promoted by current law enforcers will give the answers. For this, it is mister use other sources, not just the legal formalism [32]. In this context, Villas-Bôas [31] points out that the Brazilian Penal Code, 1940 preceding the technological revolution of the second half of the twentieth century and could not expressly provide hypotheses that order.

Lima [32] states that the validation tools of the greatest expression orthothanasia are informed con- sent and the living will that per their requirements are considered safe and valid documents. The main characteristic shared by both, so as to give orthothanasia is the manifestation of the will of the patient, preferably, has to be made before the civil capacity loss this.

For Brazilian Federal Council of Medicine (FCM), Oliveira Junior and Oliveira [23] bring that is so true that orthothanasia enjoys a reputation in Brazilian society that the Federal Council of Medicine, in 2006, issued Resolution n. 1805/2006, allowing the doctor stops the treatments that prolong the life of terminally ill without reversibility condition, with express declaration of will, or their family or legal representative. This command was approved by Resolution no. 1931/2010 of the Council, which created the new Code of Medical Ethics, effective from April 13, 2010. In relation to euthanasia, the literature stresses that the Code of Medical Ethics is categorical and prohibitive when penalizes conduct professional in "shorten the patient's life, even if the request or his legal representative" [29].

About the religious position, Bomtempo [24] brings to light evidence that: Buddhism recognizes the right of people to determine when they should pass from this existence to the next. For Buddhism mental quality of the patient's life is essential, and its decision on the time and manner of death is of paramount importance, under penalty of violation of Buddhist principles; [...] Although Judaism is against euthanasia, is not obstacle in the practice of orthothanasia; [...] To Islam, in terms of medical ethics, the Islamic Medical Ethics Code provides as oath that the doctor vows to protect human life at all stages and under any circumstances, doing his best to free her from death, disease, pain and anxiety. The doctor is an instrument of the Islamic God to cure diseases, to preserve the life and health; [...] The Catholic Church condemns euthanasia and dysthanasia. In 1995, Pope John Paul II promulgated the En- 
cyclical Vitae Evangelim. In this letter, the Pope condemns dysthanasia in this aggressive medical treatment would be inappropriate to the actual condition of the patient.

\section{Conclusion}

Bioethical issues involved in the theme of terminally fall into from proper treatment to terminally ill, to the position morally accepted in relation to euthanasia, dysthanasia and orthotanasia. Although you can think of the beginning and the end of life in a simplified and materialistic form inclusive positivist, with strict limits on medical language [25], dealing with terminal patients, especially oncologic, is not an easy task, and requires not only technical resources, provided by academic training, but above all, human resources, intrinsic to oneself (health professionals) in their relationship with each other in deep distress situation (patient) [17].

The approach of the dilemmas at the end life of ethical way does not intend to resolve them once and for all, but first, to properly understand them, understand the arguments of different positions and the weight of the limitations in the process so that the evidence is sufficient for the proper judgment of the problems that arise in the terminal patient management in oncology. Thus, despite the possible philosophical and ideological differences, it is necessary that health professionals to really take care of severe patients, prove conscious and attentive to the rights of the individual, the real meaning of the concepts of health and disease, issues the lack of therapeutic possibilities, extreme old age and death [17].

\section{References}

1. World Health Organization. Latest world cancer statistics. Global cancer burden rises to 14.1 million new cases in 2012: Marked increase in breast cancers must be addressed. Geneva, 2013. [Acess 27 February 2015]. Available: http://www.who.int/ mediacentre/factsheets/fs297/en/

2. Brasil. Ministério da Saúde. Secretaria de atenção à Saúde. Instituto Nacional do Câncer José Alencar Gomes da Silva. Estimativa 2014 - Incidência de Câncer no Brasil. [Acess in: 27 February 2015]. Available in: http://www2.inca.gov.br/ wps/wcm/connect/0129ba0041fbbc01aa4fee936e134226/ Apresentacao+Estimativa+2014_final+corrigido+tireoide.pd $f ? \mathrm{MOD}=\mathrm{AJ}$ PERES\&CACHEID $=0129 \mathrm{ba} 0041 \mathrm{fbbc01aa4fee93}$ $6 \mathrm{e} 134226$.

3. Sousa ATO, França JRFS, Santos MFO, Costa SFG, Souto CMRM. Cuidados paliativos con pacientes terminales: un enfoque desde la Bioética. Rev Cubana Enfermer 2010. 26(3): 117-129.

4. Calderón MY, Pazitková TA, Naranjo IC. Presencia de la bioética en los cuidados paliativos. Rev Cubana Med Gen Integr. 2010; 26 (2): 1561-3038.

5. Keating NL, Landrum MB, Guadagnoli E, Winer EP, Ayanian JP. Care in the months before death and hospice enrollment among older women with advanced breast cancer. J Gen Intern Med. 2008; 23(1): 11-18.

6. Barroso Fernández IC, Abalo JG. Eutanasia y cuidados paliativos: ¿diferentes aristas de un mismo problema? Psicol Salud.2012; 22(1): 1-5.

7. Garcia-Schinzari NR, Santos FS. Assistance to children in palliative care in the Brazilian scientific literature. Rev Paul Pediatr 2014;32(1): 99-106.

8. Wittmann-Vieira R, Goldim JR. Bioética y cuidados paliativos: toma de decisiones y calidad de vida. Acta Paul Enferm. 2012;25(3): 334-9.

9. Chaves JHB, Mendonça VLG, Pessini L, Rego G, Nunes R. Palliative care in medical practice: bioethical context. Rev Dor. 2011; 12(3): 250-5.

10. Pinto MH, Cruz MF, Cesarino CB, Pereira APS, Ribeiro RCHM, Beccaria LM. O Cuidado de Enfermagem ao Paciente Oncológico fora de Possibilidade de Cura: Percepção de um Grupo de Profissionais. Cogitare Enferm. 2011; 16(4): 647-53.

11. Chaves JHB, Mendonça VLG, Pessini L, Rego G, Nunes R. Palliative care in medical practice: bioethical context. Rev Dor. 2011; 12(3): 250-5.

12. Kuchner WG, Gruenewald DA, Clum N, Ezeji-Okoye SC. Implementation of ICU Palliative Care Guidelines and Procedures: A Quality Improvement Initiative Following an Investigation of Alleged Euthanasia. CHEST 2009; 135: 26-32.

13. Ferrai CMM, Silva L, Paganine MC, Padilha KG, Gandolpho MA. A bioethical reading on palliative care: characterization of scientific production on this subject. Rev Bioethikos. 2008;2(1): 99-104. 
14. Floriani CA, Schramm FR. Cuidados paliativos: interfaces, conflitos e necessidades. Ciênc. saúde coletiva. 2008; 13 (suppl.2): 2123-2132.

15. Freitas Lopes CHA, Chagas NR, Jorge MSB. O princípio bioético da autonomia na perspectiva dos profissionais de saúde. Rev gaúcha enferm 2007;28(2): 266-73.

16. Machado KDG, Pessini L, Hossne WS. The training in palliative care for the intensive care unit's team: A bioethical perspective. Rev Bioethikos. 2007;1(1): 34-42.

17. Pontes AC, Espíndula JA, doValle ERM, Santos M. Bioética e profissionais de saúde: algumas reflexões. Rev Bioethikos. 2007;1(1): 68-75

18. Rodríguez PT. Principios éticos relevantes en la atención de pacientes terminales. ARS Médica.2006; 12(12): 31-38.

19. Girond JBR, Waterkemper R. Sedation, euthanasia and the dying process of patients suffering from cancer in remedial care: understanding concepts and interrelationships. Cogitare enferm.2006; 11(3): 258-263.

20. França GV. Eutanásia: Um enfoque ético-político. Rev bioét. 2009; 7(1). [Acess: 20 jan 2014]. Available in: <http:// revistabioetica.cfm.org.br/index.php/revista_bioetica/article/ view/295/434>

21. Menezes RA, Ventura M. Ortotanásia, Sofrimento e Dignidade: Entre valores morais, medicina e direito. RBCS. 2013; 28 (81): 213-59.

22. Fernández ICB, Abalo JG. Eutanasia y cuidados paliativos: ¿diferentes aristas de un mismo problema? Psicol salud.2012; 22(1): 5-25.

23. Oliveira Júnior EQ, Oliveira BPQ. A eutanásia e a ortotanásia no anteprojeto do Código Penal brasileiro. Rev Bioethikos. 2012;6(4): 392-398.

24. Bomtempo TV. A Ortotanásia e o direito de morrer com dignidade: uma análise constitucional. Revista Internacional de Direito e Cidadania. 2011; 9: 169-182.

25. Junges JR, Cremonese C, Oliveira EA, Souza LL, Backes V. Reflexões legais e éticas sobre o final da vida: uma discussão sobre a ortotanásia. Revista bioét 2010; 18 (2): 275 - 88.

26. Marta GN, Hanna SA, Silva JLF. Cuidados Paliativos e Ortotanásia. Diagn Tratamento. 2010;15(2): 58-60.

27. Biondo CA, Silva MJP, Secco LMD. Distanásia, Eutanásia e Ortotanásia: Percepções dos Enfermeiros de Unidades de Terapia Intensiva e Implicações na Assistência. Rev Latino-am Enfermagem. 2009; 17(5). [Acess: 19 jan 2014]. Available in: $<$ http://www.redalyc.org/articulo.oa?id=281421911003>

28. Horta MP. Eutanásia - Problemas éticos da morte e do morrer. Rev bioét [Online] 2009; 7(1). [Acess: 19 jan 2014]. Available in: <http://revistabioetica.cfm.org.br/index.php/revista_bioetica/ article/view/290/429>
29. Menezes MB, Selli L, Alves JS. Dysthanasia: nurses professionals' perceptions. Rev Latino-Am Enfermagem. 2009; 17(4): 443-48.

30. Nunes R. Proposta sobre suspensão e abstenção de tratamento em doentes terminais. Rev bioét. 2009;17(1): 29-39.

31. Villas-Bôas ME. A ortotanásia e o direito penal brasileiro. Rev Bioethikos. 2008. 16 (1): 61-83

32. Lima PMS. Aspectos éticos e legais da aplicabilidade da ortotanásia. Jus Societas. 2008; 2(1): 1-20

\section{Comment on this article:}

\section{(f) $B$ in $8+\boldsymbol{S}$ ?}

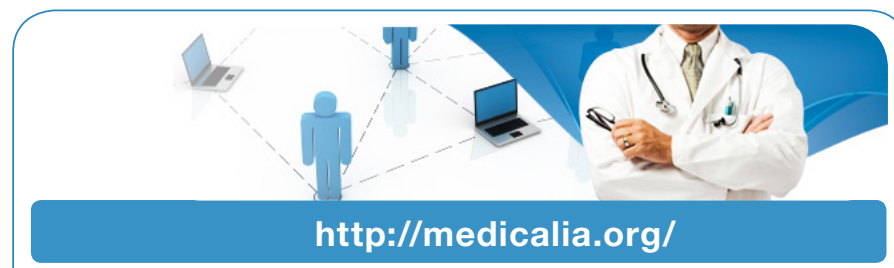

Where Doctors exchange clinical experiences, review their cases and share clinical knowledge. You can also access lots of medical publications for free. Join Now!

\section{Publish with iMedPub}

http://www.imed.pub

International Archives of Medicine is an open access journal publishing articles encompassing all aspects of medical science and clinical practice. IAM is considered a megajournal with independent sections on all areas of medicine. IAM is a really international journal with authors and board members from all around the world. The journal is widely indexed and classified Q1 in category Medicine. 